\title{
Waste Management Policy of Tourism Area in Saensuk Municipality, Thailand
}

\author{
Pongsathon Kaewmanee ${ }^{1,2}$, Andy Fefta Wijaya ${ }^{3}$ \\ ${ }^{1}$ Double Degree Master Program, Faculty of Administrative Science, University of Brawijaya, Indonesia \\ ${ }^{2}$ Faculty of Political Science and Law, Burapha University, Thailand. \\ ${ }^{3}$ Department of Public Administrations, Faculty of Administrative Science, University of Brawijaya, Indonesia.
}

\section{Abstract}

Saensuk Municipality is a famous tourism city in Thailand, especially Bangsaen beach. In supporting the tourism activity, it has waste managing method by using new generation administrator and technologies. However, the waste problem happened in Saensuk Municipality is included the human resource ability, technical facility, and the amount of waste. By using the qualitative descriptive method and doing a series of interview to selected informants, the researcher studied and analyzed the problem, factors, and solutions of the issue. This study found that the nature of the beach and the visitor behavior is among the reason behind the large amount of daily waste in the site. Moreover, the regulation by the local government is sufficient to cover the issue if fully implemented. The study shows that the city had implemented the good governance idea in several institutions, and giving the waste management to the private sector is one of the options to resolve the problem since the quality of the work could be improved.

Keywords: public policy, tourism area, Thailand, waste management

\section{INTRODUCTION}

Many years ago, Thai government invested budget to build the waste disposal system for total budget up to THB 22,000 million. The failure to handle the waste into useful thing will be a problem because in 2015 the waste in Thailand will be 49,680 tons per day or 17.8 million tons per year. Many Thai government agencies find ways to manage waste such as campaign to decrease the quantity of waste, waste separation, recycling, and invest the new technology for transform the waste to be energy (Energy Policy and Planning Office, Ministry of Energy, 2012).

In particular, the waste problem that happened in Thailand is also about wastewater. The quantity of community wastewater in Thailand is 14 million cubic meters per day. Wastewater from 1,687 municipalities are 2.5 million cubic meters per day; 6,089 sub-district organizations are 9 million cubic meters per day; Bangkok and Pattaya City are 2.5 million cubic meters per day (Department of Pollution Control, 2009: 1).

There are many Thai regulations for waste management as following:

\section{Corresponding Address:}

Email : the_kopites_@hotmail.com

Address : 49/9 Moo 6 Mitsampan Road, Banpuk, Muang Chon Buri, 20130, Thailand
- Act of Planning definition and process of decentralization to local government, 1999 (dated November 11, 1999),

- Act of Keep cleanness and tidiness of country, 1992 (dated February 19, 1992), and

- Act of Public health, 1992 (dated March 29, 1992).

From the beginning of collecting process, it is understood that Saensuk Municipality has interesting problems consisted of three points as follows:

1) Lack number of human resources of waste cleaner. They had enrolled many times but the problem is not only do not have people come to apply for a job but also the waste keepers that working had resign regularly for the Thai people think that this job is a low class job even they can get a good salary.

2) Technical problems; The City made the net in the sea for blocking the waste from the sea and keeps the beach clean from sea waste, for example, but the net always broken. It takes a lot of money to repair the net, thus it is cancelled to repair the net but still put it in the sea.

3) The amount of daily waste not only comes from the people daily activity, but also from the sea and from the tourist or visitor. The visitor does not make it by themselves and also do not bring waste from their home, 
but their waste happen when they buy some foods and beverage on site.

Another issue is about the landfill place in Bangpra Sub-district which can support the waste until only 2016.

There are many related principles and theories which using for analyzing the issue. As one of prominent ideas, the theory of good governance suggests how to govern the public in certain principles. Table 1 below shows several principles of good governance by different resources.

For the principle of Good Governance, it is concluded that it is the base of a good thinking that not only in the government sector need to have, but also private sector. In this part, if we look at Table 1, it is clear that there are six points that were mentioned from more than one source namely the Participation, Rule of Law, Transparency, Equity and Inclusiveness, Effectiveness and Efficiency, and Accountability.

Moreover, the idea of New Public Management could improve administrative of government sector by giving opportunity to professional management, improving the organization structure and operation system to be smaller structure, and promoting discipline of finance.

Table 1: Comparison among the principles (Source: UNESCAP, 2012: 2-3; Yodsomsakdi, 2006: 297298; Rule of Office of the Prime Minister, 1999)

\begin{tabular}{lccc}
\hline \multirow{2}{*}{$\begin{array}{c}\text { Good } \\
\text { governance }\end{array}$} & UNESCAP & $\begin{array}{c}\text { Thai } \\
\text { Government }\end{array}$ & $\begin{array}{c}\text { Samrit } \\
\text { Yossomsakdi }\end{array}$ \\
\cline { 2 - 4 } & $\mathrm{V}$ & $\mathrm{V}$ & $\mathrm{V}$ \\
\hline Participation & $\mathrm{V}$ & $\mathrm{V}$ & \\
\hline Rule of Law & $\mathrm{V}$ & $\mathrm{V}$ & $\mathrm{V}$ \\
\hline Transparency & $\mathrm{V}$ & & \\
\hline Responsiveness & $\mathrm{V}$ & $\mathrm{V}$ \\
\hline $\begin{array}{l}\text { Consensus } \\
\text { oriented }\end{array}$ & $\mathrm{V}$ & & $\mathrm{V}$ \\
\hline $\begin{array}{l}\text { Equity and } \\
\text { Inclusiveness }\end{array}$ & $\mathrm{V}$ & & \\
\hline $\begin{array}{l}\text { Effectiveness } \\
\text { and Efficiency }\end{array}$ & $\mathrm{V}$ & $\mathrm{V}$ \\
\hline Accountability & $\mathrm{V}$ & $\mathrm{V}$ & \\
\hline Moral & & $\mathrm{V}$ & \\
\hline Value & & $\mathrm{V}$ & \\
\hline
\end{tabular}

Furthermore, the principle of citizen participation allows the public to be involved in governing their life. In Saensuk Municipality, for example, inhabitants can participate in waste management which the information will be analyzed by the idea that discuss before.
Particularly in waste management, the principle of $4 \mathrm{Rs}$ for the waste management is significant, namely [21]:

- Reduce means reducing the amount of waste produced each day by using less. For example when buying products look for those that use the least amount of packaging.

- $\quad$ Reuse is to keep using something before we either recycle it or dispose it. Storing food in reusable containers rather than disposable bags is one example of reusing.

- Recycling many things such as drink containers, newspapers and some plastics. Recycling is the process of taking a product at the end of its useful life and using some or all of it to make another product. When using things that cannot be reused, must ensuring that those things are made of materials that can be recycled.

- Recovering materials or energy from waste that cannot be reused or recycled. Recovering energy from waste materials is a growing technology.

Therefore, it is understood that how to do the good way for solving the waste problem and using for waste management.

Moreover, this paper is about Saensuk Municipality wastewater control related to wastewater problems. According to Ministry of Natural Resource and Environment, Department of Pollution Control surveyed the potentials of community wastewater treatment in Thailand since year 2005 to 2009 which there are three problems, namely: 1) the system operation and maintenance, 2) the management readiness, 3 ) the knowledge and participation in system management.

The research was taken place in Saensuk Municipality, as one of the most interesting places in Thailand for tourist attraction.

\section{METHODS}

Figure 1 shows the map and location of Bangsaen beach, Thailand as the study location.

\section{Data Collecting Method}

This research is a qualitative method in social research. The focus of research is on waste management process, and many related factors on the process. The study points to three points are namely the waste management, the factors, and the solution. 


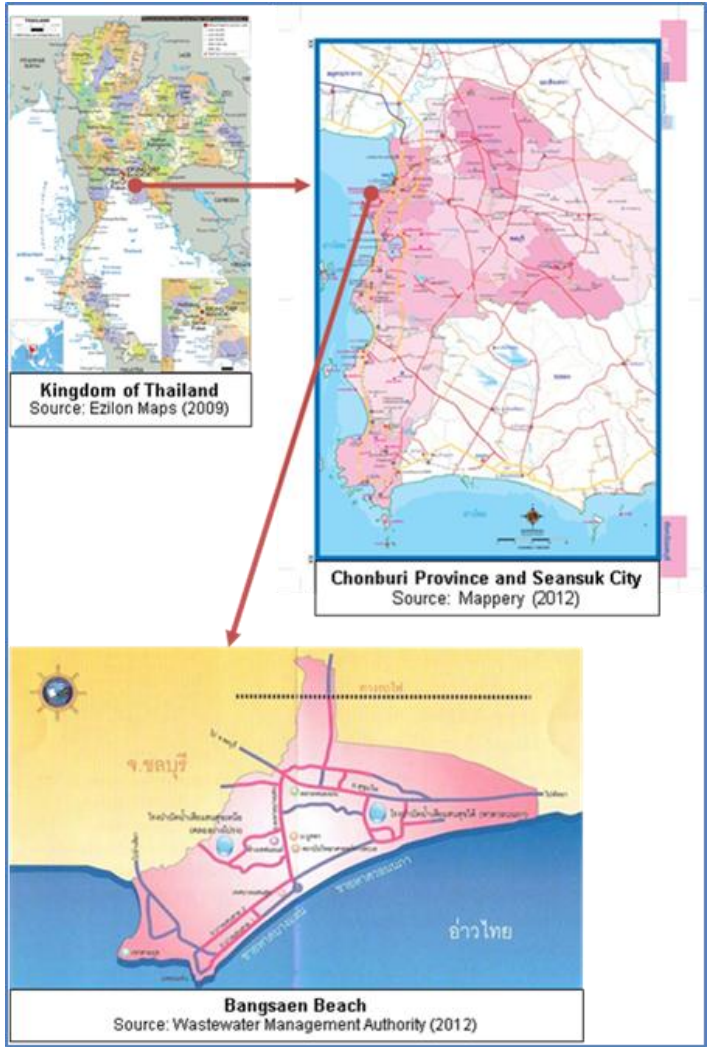

Figure 1. Map of Bangsaen Beach and Seansuk Municipality

Moreover, the study found the supporting and obstacles factors in the waste management, the implementation of waste management, and the solutions for solving the problems in the waste management policy. For the interview session, the purposive selected informants were chosen, thus, there was interview session to the Mayor, the Head of Cleanness Department, the Director of Public Health and Environment, Traders, and the local populations.

\section{Data Analysis Method}

As a qualitative research, this study employs the logical approach to analyze the findings and data and draw the conclusion at the end. The data gathering and analyzing process were conducted in a simultaneous way. Analysis of the data used in this study consists of three activities, namely [20]

a) Data Reduction is by summarizing, choosing, and focusing on the important things, looking for themes and patterns. In this case, the policy implementation was investigated.

b) Data Display is compiling and presenting the information for later use in reporting research results. c) Drawing Conclusion is by giving initial conclusions as a tentative one, and changed if not found strong evidence to support the next phase of data collection. Valid evidence supported suggestions and consistent conclusions will put forward as a credible conclusion.

\section{RESULTS AND DISCUSSIONS}

Seansuk Municipality is directed by a Mayor who is assisted by several officials and agencies. For taking care waste management, there are two divisions: Division of Public Health and Environment and Division of Sanitation Mechanic which had obviously separated responsibility. The Division of Public Health and Environment has responsible in keep cleanness part, while the Division of Sanitation Mechanic has responsible in waste and filth disposal part, waste and filth factory part, and wastewater treatment control and checking part.

The waste management of Saensuk Municipality in the present is beginning to the new period of development, technology, and method for helping in waste management to be sustainable. From interviewing the Mayor, it is known that Saensuk Municipality has managed the waste under many principles such as public administration and management, good governance, new public management, citizen participation, and the $4 \mathrm{Rs}$ (reduce, reuse, recycle, and recover). In the past, Saensuk municipality had manage waste in old style of government organization but in the present, Saensuk municipality has bringing many ideas of private company to apply in waste management as the result of globalization and the experience of the Mayor (Mr. Narongchai Khunluem). In Saensuk Municipality, the Mayor is the key person in development because he had created and implemented many new methods for managing or solving the problem in Saensuk Municipality waste management by sharing the responsibility to several actors, public and private. The local government is also increase the budget. Seansuk municipality is the government organization which has to follows many of government regulations for administration. In operation, they operate with the strategies, internal management, and external cooperation to be the supporter in organization administrative. For the operation method, Saensuk municipality had separate Saensuk city area to 11 areas which some parts hire the private company to operate on the main roads 
and the other parts will operates by the municipality employee. The operation time of waste management is since 05:00 until 16:30 to avoid to disturbing the population and tourists activity.

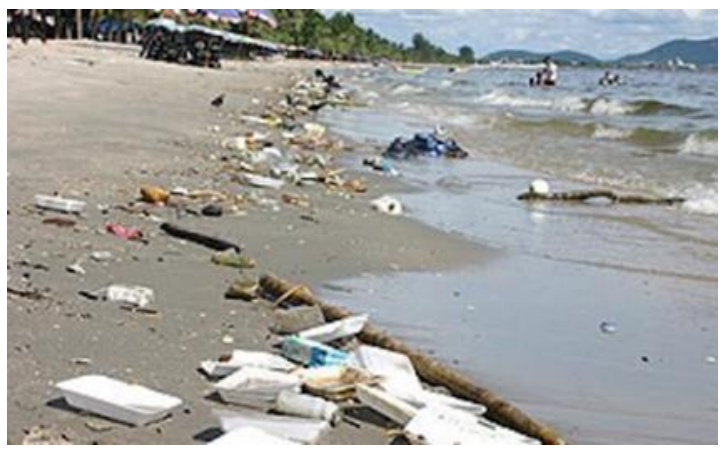

Figure 2. Waste on Bangsean beach as in daily situation (Source: Seansuk municipality)

Moreover, there are many problems in waste management are human resource, material, tool, and limited landfill place were solved by the Saensuk municipality hire the private company in many projects. The project of hiring private company for sweep and manage waste on the main road for solves the problem of human resource, tool, and material. The project of hiring the private company for build the waste separation factory for solves the problem of limited landfill place and can be a benefit from the recycling of waste. The project of hiring the private company for collecting waste in sea to solve the problem that the net to block the waste is cannot work in efficiency and had problem of human resource.

For the term of citizen participation, even there are 43 communities, but the citizen participation is low and limited. The participation in waste management, although the municipality has the idea, there is not much citizen's participation. They mostly just complaining and suggesting more than helping and participating for together managing waste in sustainable method.

There are many factors that have the impacts to waste management in Saensuk municipality such as supporting factors and obstacles factors. The supporting factors are the municipality budget, the leader and administrator capacity, location and places, other organizations relations, and Saensuk communities. The obstacles factors are population cooperation, tourist's behavior, number of human resource (waste keeper), materials and tools, and natural factor.

According to the interview with the Mayor, the first supporting factor is "the vision administrators" which had to accept that the administrator is the factor that has impact to every parts of organization and other factors. If the administrators are good, meaning that will be a high level to be a supporting factor for other factors to be good factors. And for the first obstacle factor is "the cooperation in waste management of the population" because they are not recycling, separating, and never change their behavior.

Moreover, another important obstacle factor is the natural, because the sea in Thai gulf flowing from left to right which brings a lot of waste from three river mouths to Bangsaen gulf. The garbage is disposing in other city but flowing to Bangsaen makes the municipality has to spend lot of money in every year for managing this problem.

Therefore, in overall of Saensuk municipality can manage waste in efficient way by many elements such as administrators, budget, staff, materials, the control planning, and evaluation for improve and solve the weakness of waste management. Which all of these supporting factors and elements of Saensuk municipality make them can manage waste in efficiency and sustainable.

From problems and obstacles in waste management of Saensuk municipality such as population and tourists, number of employee, materials, natural, and the place for landfill become the solutions in many methods. Every solving method is from the problem study and mayor decisions which has objective to manage waste in sustainable which there are many methods are as following:

1) Hiring private company for cleaning footbath and sweeping roads. The municipality has operated this project since 2012 which are a good result and in 2013 the Saensuk municipality hires the private company for manage more areas. This project can solve the problems of number of employee and materials which are lightening the load of municipality and can be solved the problem in good result.

2) The employment of the private company for keeping waste in the sea. Bangsaen gulf get the impact from the sea tides that flow waste from three of main river in Thailand especially Chao Phraya river and 
Bangprakong river. The sea tides in Thai gulf are flow from left to right which bring a lot of waste to Bangsaen beach. In the past, Saensuk municipality had built the net for block waste before to the beach and bought the waste keeping boat for keep waste from the net. The problem of net is there are waste unrecorded to the beach, had often to spend a lot of money for repair the net in every year, the waste keeping boat cannot support the quantity of waste, the number of waste keeper are not enough, and when the seaweed stick with the net for a long time it will be rot and stank. So, the municipality of Saensuk hires the private company that has experience for manage waste in the sea for manage waste from the sea in Bangsaen gulf.

3) Term of reference in giving the private sector to be the investor for constructing and managing the operation system of waste disposal efficiency is increasing. This project is the project for solving the problem of landfill place that will be full in 4 years and increasing the efficiency of waste management by dismantle the old waste sump for bring the old waste that can recycle and can be the benefit for sell and benefit using which will make more empty area for landfill in longer time, will build the separation factory of separate and recycle of waste which will could recycle waste around $80 \%$ and bring for landfill only around $20 \%$. This project will be a project for solving many problems in a long term.

4) The project of reducing of foam using in Bangsaen beach area. This projects is supporting waste management in sustainable in principle of $4 \mathrm{Rs}$ are reduce, reuse, and recycle. The quantity of waste in Saensuk city mostly from Bangsaen beach area and most of the waste on Bangsaen beach area is foam. The municipality had meeting with all the stakeholder which the result is avoid to use foam and use the material that can reuse or the natural material because foam is the thing that not easy to degradation.

There are two solutions for Saensuk municipality waste management problem, which are the private company hiring and cooperation of municipality and citizen. The private company hiring is the solving method which fulfill the weakness of municipality management especially in action which can solve and fulfill in short and long term. The private company hiring is a good choice because there are many problem in regulation which when hire the private company makes the operation system is easier. For the cooperation of municipality and citizen, one of a good projects is decreasing foam using on Bangsaen beach which not only can solve the quantity and duty of waste management, but also can makes the other problem easier to solve such as the problem of waste sump.

However, even there are many projects for solved the waste problems but it is not a solving way in sustainable. The sustainable way should be the cooperation from all of the stakeholders are the population, tourists, and municipality to do the reduce, reuse, recycle, and recover from waste which will be a solving way in sustainable. And from the analyzing with the theories can conclude that most of the points from the theories of public administration and management such as good governance and new public management, also citizen participation and principle of $4 \mathrm{Rs}$ are related with the waste management way of Saensuk municipality which there are only some points of them that the Saensuk municipality did not do in the same direction.

To sum up, the waste management in Saensuk municipality has some success parts by finding the way for solving and managing the waste issues. In the future, the problem will not happen if the Saensuk municipality private company cans operation in waste management well and is in their objective but if they cannot manage it well the new problem will come absolutely.

\section{CONCLUSION AND SUGGESTION Conclusion}

The operation of waste management in Saensuk municipality is under Act of Planning definition and process of decentralization to local government in 1999, Act of Keep cleanness and tidiness of country in 1992, Act of Public health in 1992, Announcement of Wastewater management organization in 1999, and many municipal laws.

Nowadays, Saensuk municipality is in the new period of administration and development which many problems had already solved and many problems will be solve in future soon. The waste problems solving of Saensuk municipality 
are solving under bureaucracy that has good governance which everything is going well.

There are supporting factors and obstacles factors of waste management in Saensuk municipality. The first supporting factors is the administrator vision which the administrator of Saensuk have the vision to solve the problem in a long term. The second supporting factor is mayor are knowledge and capability from his experience also the background which he is in the politician and business family makes he know a lot in administration. The third supporting factor is organization capacity which Saensuk has been ready in budget, human resource, and material.

The fourth supporting factor is duty specification and assignment which this is the main working of waste management. All of these are the supporting factor that makes the Saensuk municipality be the strong local government organization in waste management. The obstacle factors are the population that not cooperation to reduce and recycle waste, and the natural factor that the sea flow a lot of waste from the river mouth to Bangsean beach which this factor the Saensuk municipality cannot control it.

However, the supporting and obstacle factors may can changing or will be solve soon because the Saensuk municipality knows all the problems and operating to solve it. For the citizen participation, being the big problem even the citizen has some participation but just in case of administrative and management which in action, the citizen do not cooperation for solve waste problem in sustainable.

Moreover, the Natural factor is an important factor because the tides flow a lot of waste to Bangsaen beach which not only the Saensuk municipality has to spend a much money to solve this problem but, also the sea waste has an effect to the beach which destroying scenery and travel atmosphere.

\section{Suggestion}

We suggested that the Municipality should promote to the population to give cooperation in reduce, reuse, recycle, and recover. Also, the Saensuk municipality should support the project of Bangsaen beach with no foam by find the new material for sell in Saensuk area which it will be facilitation and makes the population and trader want to cooperation in using the material that can biodegradable. They also need to do the spare plan in case that the private company cannot operate on municipality planning which it will be serious impact to the Saensuk municipality in the future.

The city has to do the coordinate with the central government and the local government on the mouth of both rivers for cooperate in solve the problem together which will be a solving at source of waste in the sea.

\section{ACKNOWLEDGEMENT}

My deep appreciation goes to Obed Milton Simamora, SH, MMG, and also to Prof. Samrit Yossomsakdi, Ph.D. for helping me writing and publishing this article, and kindly assisting during my study.

\section{REFERENCE}

[1]. AllisonG. 1982.Public and Private Management: Are They Fundamentally Alike in All Unimportant Respects. Frederick S. Lane (ed.) Current Issues in Public Administration. St Martin's Press. New York.

[2]. Chanchampee P. 2010. Methods for Evaluation of Waste Management in Thailand in Consideration of Policy, Environmental Impact and Economics. Aus Bangkok. Bangkok.

[3]. Mize, CE. 1972.Citizen Participation in Public Decision-making: a Study of the Willamette National Forest. School of Community Service and Public Affair. Oregon.

[4]. Cogan A, Sharpe S, Hertzeberg J. 1986.CitizenParticipation, Chapter 12 in The Practice of State and Regional Planning, edited by Frank SS, Irving H, McDowell BD. American Planning Association. Chicago.

[5]. Denzin N,Lincoln Y. 1994. Data Management and Analysis Method: Hand Book of Qualitative Research. SAGE.California.

[6]. Department of Alternative Energy Development and Efficiency. 2010. The quantity of waste in Thailand. Ministry of energy. Bangkok.

[7]. Energy Policy and Planning Office (EPPO). 2012. Energy from Waste, Ministry of Energy. Retrieved from: http://www.eppo.go.th/engy/Load/ET13.pd f accessed at $23^{\text {rd }}$ April 2012.

[8]. Family Health International. 2012. Qualitative Research Methods Overview. Qualitative Research Methods: A Data Collector's Field Guide. Research Triangle Park. Family Health International. Carolina. 
[9]. Frederickson HG, Smith KB. 2003. The Public Administration Theory Primer. A Member of the Perseus Book Group. New York.

[10]. GerthHH, Mills C. 1970. Public Management and Administration. Max Weber: Essays in Sociology. Routledge \& Kegan Paul. London.

[11]. Intarasaard K. 2008.People's Opinions towards and Participation in Community Garbage Collection Management of Tambon Weing Fang Municipality, Fang District, Chiang Mai Province. Master thesis: Rachapat Chiangrai University. Thailand.

[12]. Jantawatsiri N. 2007. The Attitude of People towards the Garbage Service of Ubon Ratchathani Municipality, Thailand. Master thesis. Rachapat Ubonrachatanee University. Thailand.

[13]. Kirunda MP. 2009.Public Participation in Solid Waste Management: Challenges and Prospects. A case of Kira Town Council, Uganda. Master thesis. The University of Agder. Kmistansand.

[14]. Lance JE. 2000. New Public Management. The Taylor \& Francis. New York.

[15]. Laurence E. 2006.Public Management Old and New. Taylor \& Francis e-Library. Milton Park, Abingdon.

[16]. Ministry of Natural Resource and Environment. 2010. The Reporting of Checking and Efficiency Evaluation: The Collecting System and the System of the Eastern Area Community Wastewater Treatment. Bangkok.

[17]. Pradhan UM. 2008.Sustainable Solid Waste Management in A Mountain Ecosystem: Darjeeling, West Bengal, India. Master thesis. Faculty of Graduate Studies, Manitoba University.

[18]. Rakthai. 2009. A Case Study of Waste Problems on Bangsaen Beach [Internet] Chonburi. Available from:< http://rakthairakthai.blogspot.com/2009/08/blogpost.html> [Accessed on February 18, 2012]

[19]. Saensuk Municipality. 2012. The Overall in Operation of Waste Disposal Center. Seansuk, Thailand.

[20]. Sugiyono. 2007. Metode Penelitian Kuantitatif, Kualitatif dan R \& D. CV. Alfabeta. Bandung.

[21]. Think Green. 2009. The 4Rs Defined, Waste Mangement. Discovery Education. A Division of Discovery Communications, LLC. Maryland
[22]. UNEP. 2004. State of Waste Management in South East Asia. United Nation Publication. New York.

[23]. UNESCAP. 2012. What is Good Governance? UNESCAP. Thailand.

[24]. Yossomsakdi S. 2006. Public Administration: Principle and Theory. Thailand

[25]. Regulation of Hiring the private company keeps cleanness, road sweeping, footbath sweeping, and public areas sweeping in Saensuk Municipality. 2013. Thailand.

[26]. Regulation Details and Scope of Hiring the private company for collect waste in the sea, Saensuk municipality. 2013. Thailand.

[27]. Rule of office of the Prime Minister in the creating of good governance system. 1999. Thailand.

[28]. Term of Reference draft to give the private company to be the investor fir build and operation the system of the waste disposal efficiency increasing, Saensuk Municipality. 2013. Thailand.

[29]. Act of Planning definition and process of decentralization to local government. 1999. Thailand.

[30]. Act of Keep cleanness and tidiness of country. 1992. Thailand.

[31]. Act of Public health. 1992. Thailand.

[32]. The Saensuk municipality's three years Development Planning 2012-2014. 2011. Thailand.

[33]. The Saensuk municipality's development strategy 2010-2014. 2009. Thailand.

[34]. The Saensuk municipality's operation planning 2010-2012. 2009. Thailand 